\title{
$\mathrm{CO5428}$
}

\section{Empirical Analysis of Firms' Willingness to Participate in Infrastructure PPP Projects}

\author{
Xiaosu $\mathrm{Ye}^{1}$; Shiying $\mathrm{Shi}^{2}$; Heap-Yih $\mathrm{Chong}^{3} ; \mathrm{Xiao} \mathrm{Fu}^{4}$; Lihong Liu ${ }^{5}$; Qiong $\mathrm{He}^{6}$
}

1.Professor, School of Construction Management and Real Estate, Chongqing University, Chongqing 400045, China. [Corresponding author] E-mail: xiaosuye5711@126.com.

2. Ph.D. Lecturer, School of Civil Engineering, Henan Polytechnic University, Jiaozuo 454003, Henan, China

3.Ph.D. Senior Lecturer, Department of Construction Management, School of Built Environment, Curtin University, GPO Box U1987, Perth, WA 6845, Australia.

4.Ph.D. School of Economics and Management, Chongqing University of Posts and Telecommunications, Chongqing 400065, China.

5.Ph.D. candidate, School of Economics and Management, Beijing Jiaotong University, Beijing 100044, China.

6. Ph.D.candidate, Department of Civil Engineering, Faculty of Engineering, University of Hong Kong, Hong Kong, China.

Abstract: Private participation is the key element in forming public private partnership (PPP). Numerous studies have identified the factors of private participation in infrastructure projects, but previous results rarely focused on the willingness to participate in infrastructure 
PPP projects from the private sector's perspective. This research examines the factors of the private participation in PPP when considering willingness to participate as a function of internal (i.e., a firm's nature) and external factors (i.e., institutions, government behavior, and project characteristics). Using the logistic regression model and the data from the questionnaire survey, this research finds that nine variables have a significant coefficient, i.e. profitability, political connection, government intervention, government support, project complexity, and project experience; especially for those companies with more project experiences, political connection and higher profitability are more likely to be willing to participate in PPP projects. In contrast to previous studies, the research finds no support for the effect of institutional environment and public support on firms' willingness to participate in PPP. These findings can serve as a valuable reference in shaping the private sector's motivation to participate in PPP. Factors of private participation in PPP projects are explained and discussed in the context of the Chinese PPP experience and practice.

Keywords: Public Private Partnership; Private Participation; Willingness; Profitability; Experience; Political Connection

\section{Introduction}

Due to fiscal constraints, inefficiencies in service provision, and the pressure of infrastructure demands, governments need to use limited public resources to attract and leverage private capital (Ranasinghe, 1998; Lin, 2013) and implement innovative mechanisms to improve provision efficiency (Savas, 2000; Hart, 2003). One such mechanism is public private partnership (PPP), which takes advantage of specific qualities between the public and private 
partners to provide public service, meet public demands, and attain added social values (Tecco, 2008; Steijn et al., 2011; Engel et al., 2013). Shen et al. (2016) noted that the demand for PPP infrastructures is increasing in China whilst there are increasing numbers of PPP projects in the country. From 1984 to 2013, there were 1,236 projects involving private investment, with 38 percents of the investors from mainland China (World Bank PPI Database, 2015). From 2014 to 2015,2,767 PPP projects are initiated by the central government with a total investment of around 5069 billion RMB (Ministry of Finance of China, 2015; National Development and Reform Commission of China, 2015). However, only about 20 percent of these PPP projects are contracted (Chen, 2015), which indicates that the private sector is hesitant to participate in PPP projects and they are in a decision-making dilemma.

Participating in PPP is not only an opportunity for private companies to expand into new markets and to achieve the long-term business prospects (Crosslin, 1991; Hodge and Greve, 2007; Ke et al., 2013; Zhang and Soomro, 2015), but also a challenge to deal with more risks and uncertainties (Nijkamp and Rienstra, 1995; Koppenjan and Enserink, 2009). Therefore, decision making for private companies in getting involved in PPP projects is more complex and important than traditional investment. Mutil-facets research has presented several requirements for private involvement in PPP projects. First, from the perspective of project success, an experienced, strong and good private consortium is the most important factor of a successful PPP/ Private Finance Initiative (PFI) projects ( $\mathrm{Li}$ et al., 2005). In addition, the planning and management capabilities of PPP project implementation (Yun et al., 2015; Zhang, 2005a), organizational form, managerial strategies (Steijn et al., 2011), technical strengths (Ng et al., 2010) and commitment 
(Zou et al., 2014), are also critical factors for private involvement in PPP. Second, as creating value is the critical purpose of PPP projects, the private partner should possess some traits, such as value-added capacities (Steijn et al., 2011), entrepreneurship (York et al., 2013), resource complementarities (Kivleniece and Quelin, 2012), trust and confidence (Panda, 2016), to create and ensure value for money (VFM), minimize transaction costs, and achieve positive externalities (Mouraviev and Kakabadse, 2015; Kivleniece and Quelin, 2012). Third, from public sector's perspective, as selecting partners directly influences the PPP project performance (Song and $\mathrm{Xu}, 2011$; Ouenniche at al., 2016), the public sector will make some requirements about the partner, such as firm size, project experience, financial capacity, and commitment (Farquharson et al., 2011; Boussabaine, 2014; Zhang, 2005b), so as to choose the right partner for service provision. Finally, in terms of how to attract or promote private participation, previous research has also provided some attractive conditions, such as project profitability or stable cash flows (Koppenjan and Enserink, 2009; Panayiotou and Medda, 2014), long-term commitments (Akhmouch and Kauffmann, 2013), quality of institutions (Percoco, 2014), and fair risks allocation (Tecco, 2008), which increase the likelihood of private participation in infrastructure projects. Above all, various studies have provided important insights about partners' attraction and selection, which contributed a lot to public sectors in setting up boundaries for private participation.

A true partnership is two-sided, which is akin to marriage or employment (Burdett and Coles, 1999; Bovaird, 2004). While public sector is evaluating a potential private partner, the private partner is also evaluating the public sector. It is this two-sided aspect of the problem that 
generates a significant interest. Compared with rich discussions about how public sectors should select private partners, the willingness to participate in PPP projects are rarely discussed from the private sector's perspective. Therefore, it is essential to investigate the private sector's willingness and to analyze the factors for participating in PPP projects. This research first investigates the private sector's willingness to participate in PPP and analyzes the critical factors on private participation in PPP. And then the regression model is adopted to explain and evaluate the relationships between the private sector's willingness and its factors based on the data from a questionnaire survey.

Section 2 reviews the theoretical background and proposes hypotheses for the empirical study based on the relevant literatures. Section 3 discusses the method and presents the study's data. Section 4 presents the results. Section 5 discusses the results of the empirical analyses, and Conclusions and limitations are provided in section 6.

\section{Theoretical Background and Research Hypotheses}

\section{Theoretical background}

Private capital is allowed or encouraged to participate in infrastructure projects for service provision due to the inefficiency results of government monopolizing public service provisions and limits of government financial deficit for public investments (Grimesy and Lewis, 2004; Zhang, 2014), but a great amount of infrastructure investment require the private sector to be more cautious in decision making. Neoclassical economics is the traditional method of carrying out an investment analysis, and the rate of return on investment is considered as a critical parameter of the investment decision. An investor's goal is to maximize utility objectives (Fisher, 
1930), although an investment can be uncertain or risky, the results of which may jeopardize future benefits (Hirshleifer, 1965). And special investment or uncertainty could increase transaction costs in the process of service provisions (Williamson, 1999). Resources exchange and constructing partnership are essential to make investments, lower transaction costs, and/or solve social problems (Ham and Koppenjan, 2001; Kivleniece and Quelin, 2012), which are related to the resource dependence (Pfeffer and Salancik, 2003). In addition, appropriate government support and better institutional environment also play important roles in public service provisions that private companies participate in (North, 1987; Percoco, 2014; Wibowo and Alfen, 2015). Therefore, when choosing amongst a set of investment projects and evaluating all the alternatives, the decision-maker not only needs to take into account investment periods, cash flow, available information, and uncertain factors (Smith, 1971; Cantor and Lippman, 1995), but also to take into consideration the nature of the project, partner's characteristics, and institutional environment, so as to make informed judgments and achieve the goal.

\section{Identifying the factors}

The factors are identified in the following three steps.

First, according to the Investments, firm's investment decision is closely related to its nature (i.e. profitability, financial situation, expertise or experience), external environment (i.e. political, economic or social environment), and investment targets (i.e. its profitability, complexity or uncertainty) (Hirshleifer, 1965; Gatti, 2013; Bodie et al., 2014). Theses factors are used to define the boundary of this research.

Second, from the perspective of improving competitive advantage for wining contracts, the 
financial of Consortium, government guarantee and project nature are the important critical success factor (CSF) in winning a Build-operate-transfer (BOT) project (Tiong et al., 1996). In addition, political connections help firms to gain valuable and rare resources which cannot gain from the market (Li et al., 2006), and these resources are the source of the competitive advantage (Barney, 1991; Li et al., 2006). Meanwhile, political connections help firm to sustain some level of profitability (Jensen, 2016); and Li et al. (2006) found that political participation makes it easier for firms to start private business in China.

Third, from the perspective of PPP project success, it requires that the team must consist of members who are financially sound so that they are able to bear and share the huge development costs and have sufficiently financial capable of taking up the projects (Wang et al ., 2000; Chan et al ., 2010; Soomro and Zhang , 2015; Song et al ., 2016). Meanwhile, risk and public opposition have important effect on project profitability (Tiong et al., 1992; Hodge and Greve, 2007; Li et al., 2012; Boyer et al., 2016), while project profitability is a precondition for private investors choosing and participating in PPP project (Mayer, 2007; Gross and Garvin, 2010; Sclar, 2015). In China, governments play an important part in determining the PPP project success, especially too government's intervention will produce more risks resulting in project failure, and then project failure has very important effect on project profitability and recovering the investments. Therefore, Tentative factors are listed according the above reviews, which are corporate financial status, firm profitability, firm political connections, institutional environment, government intervention, government support, project complexity, project profitability, public support, and PPP project experience. 
In order to verify the selected factors, eleven professors were invited to review and comment. They are from 11 universities in different areas in China, which are from Beijing (Tsinghua University; Beijing Jiaotong University), Chongqing (Chongqing University), Jiangsu (Southeast University), Shanghai (Tongji University), Tianjin (Tianjin University; Tianjin University of Technology), Zhejiang (Zhejiang University), Sichuan (Sichuan University), Shanxi (Xi'an Jiaotong University), and Liaoning (Dalian University of Technology). Moreover, a workshop was conducted to discuss and review the variable list, of which the participants include professors, PPP project managers, and local government officers. Both verification processes come out with same results that project profitability should not be included in the factor list, as it is the precondition for project sponsor to attract investors' participation in PPP project. And meanwhile, private sector should first judge whether they are capable of maximizing the project profitability when they win the contract.

Finally, nine factors are selected, which are corporate financial status, firm profitability, firm political connections, institutional environment, government intervention, government support, project complexity, public support, and PPP project experience.

\section{Research hypotheses}

An important factor of investment is profitability (Nijkamp and Rienstra, 1995; Bodie et al., 2014). First of all, the complexity, high risk and long-term project life cycle in PPP projects require significant amount of capital and long-term financial support from private companies to support these investments (Gatti, 2013; Bodie et al., 2014). Second, financial strength is the critical factor in winning a project (Tiong et al., 1996; Chan et al., 2010), and it has effect on 
partnership failures in PPP project (Soomro and Zhang, 2015). Firm profitability is an important indicator of explaining the financial capability or financial strength (Cleary, 1999; Bodie et al., 2014). Therefore, this research proposes the following hypothesis:

Hypothesis 1a (H1a). Firms with higher profitability are more likely to participate in PPP.

An enterprise's investment decision is directly related to its financial situation (Cleary, 1999). Hirth and Viswanatha (2011) found that a firm's financial situation or financing constraints influenced its investment behavior. The enterprise's financial resources had a direct impact on its decision to engage in potential investment projects; Bodie et al. (2014) suggested that the debt-asset ratio has a significant and positive correlation with enterprise's financial situation. Tiong (1996) suggested that reasonably high equity to debt ratio is the critical factor for $\begin{array}{llll}\text { the } & \text { private } & \text { to }\end{array}$ the build-operate-transfer concession. In addition, as investing in infrastructure PPP projects requires "seed" capital, so the opportunities for investment will increase when there are ample self-owned assets (Kim et al., 2008). Therefore, this study constructs the following hypothesis:

Hypothesis 1b (H1b). Better corporate financial status will effectively encourage private participation in PPP.

Political connections help firms gain a competitive advantage. Osei-Kyei and Chan (2015) suggested that the necessary support from political leaders attracts more investors to a particular economy. Li et al. (2006) found that the entrepreneur's political participation can help the firm reduce transaction cost and acquire some beneficial resources, such as favorable regulations, tax deductions and legal protection, which these resources cannot gain from the market. The 
resource-based view argued that valuable, rare, imperfectly imitable, and nonsubstitutable resources are a source of competitive advantage (Barney, 1991). Moreover, in order to sustain some level of profitability, firms agree to perpetuate a low-level equilibrium of suppressed tariffs and minimal investment to meet political aims throughout the Asian countries (Jensen, 2016). In China, Li et al. (2006) found that political participation makes it easier for firms to start private business, so many firms actively participate in politics or establish the relationship with the important government bureaucrats, especially becoming the member of the National People's Congress (NPC) of China or the Chinese People's Political Consultative Conference (CPPCC). Therefore, this study proposes the following hypothesis:

Hypothesis 1c (H1c). Political connections will positively influence private involvement in PPP.

Better institutional environment will positively influence private participation in infrastructure investment. When private investors make decisions about participation in PPP, they need to carefully assess the institutional features (Farquharson et al., 2011; Zhang, 2014) and the quality of institutions (Percoco, 2014). Elaborate institutions can sustain the cooperation, reduce uncertainty in exchange, and prevent the activity of cheating, shirking or opportunism (North, 1987, 1991). From a new institutional economics perspective, PPP, as a new institutional arrangement, involves significant transaction costs (Reeves, 2008) and is closely related to its institutional environment (Zhang et al., 2015). However, the weak quality of institutions will result in investment risks, which raise the cost of capital by 2-6\% (Guasch and Spiller, 1999), and it may result in the private sector facing contract renegotiation. In addition, as infrastructure 
investments possess a high degree of asset specificity (higher sunk cost), private investors are hesitant to make decisions under such circumstances without adequate contractual or institutional protection (Dailami and Leipziger, 1998). Therefore, the better the institutions are in terms of lower corruption, civil freedom and better regulatory frameworks, the greater willingness is to participate in PPP projects (Percoco, 2014). Hence, the constructed hypothesis is as follows:

Hypothesis 2 (H2). Better institutional environment can positively affect private participation in PPP projects.

Governments play an important part in determining the PPP project success by eliminating legal or regulatory constraints and supporting appropriate private investments, and they also play a key role in creating a favorable investment environment in which the private sector feels it can obtain a commensurate return (Wibowo and Alfen, 2015). High-quality support from the government also improves the investment performances of the private sector (Nijmeijer et al., 2014), involving government commitment, revenue guarantee, trust, and information transparency (Queiroz et al., 2013; Xu et al., 2014). Kirama and Mayo (2016) suggested that the success of private sector participation system need government support by raising the awareness of the communities and discourage illegal dumping of waste in Tanzania. However, the government intervention would create risks in PPP projects that could influence the project profitability (Ke et al., 2013) and increase transaction costs as private investors spend too much time maintaining a good relationship with the government. Featuring critical interdependencies between public and private interests (Mahoney et al., 2009) and PPP value-creating mechanisms (Kivleniece and Quelin, 2012), these relationships require an examination of the underlying 
public sector's factors to understand its impact on private participation decisions. Hence, the constructed hypotheses are as follow:

Hypothesis 3a (H3a). Government support will positively affect private involvement in infrastructure PPP projects.

Hypothesis 3b (H3b). Government intervention will negatively influence private participation in infrastructure PPP projects.

Project characteristics are related to private involvement in infrastructure PPP projects. Project complexity raises some difficulties in involving financial, technical and management, which will prolong concession periods and/or result in PPP project failure (Jin and Zuo, 2011). Especially, larger projects will raise the transaction costs in PPP, increase the uncertainty around future willingness-to-pay for use (Koppenjan, 2005; Vining and Boardman, 2008), and even diminish the utility or quality of service provision (Soliño and Santos, 2016). Albalate et al. (2015) also found that infrastructure characteristics are critical factors influencing private participation. Moreover, as complex projects may require more inputs for service provisions, private investment will be recovered through the operation revenue over a concession period and the appropriate discount rate, which directly affect the investors' interests and risk allocation (Shen et al., 2002; Regan et al., 2011). Hence, the constructed hypothesis is as follows:

Hypothesis 4 (H4). Project complexity will negatively affect private participation in the infrastructure PPP projects.

Public participation can influence the outcomes of infrastructure projects (Li et al., 2012), but lack of public support often causes the failure of a project and general resentment (Zhong et 
al., 2008). The public involvement could improve the project performance and overall transparency (Boyer et al., 2016). In addition, the willingness of end-users to pay may influence the cash flow of infrastructure PPP projects, which further affects the rate of returns on investment of private firms. Therefore, this research proposes the following hypothesis:

Hypothesis 5 (H5). Public support will positively affect private involvement in PPP.

Experience can improve organizational capabilities and enhance performance (Sampson, 2005), because it helps companies shape and refine their routines by decreasing the complexity and simplifying the process in the current setting (Levinthal and March, 1993). Moreover, sufficient past experience will inform the parties as to what might or might not happen over a project's life-cycle, and the firm can use its past experience to predict or assess risks so that an efficient risk allocation can be achieved (Iossa and Martimort, 2012). In addition, Bodie et al (2014) suggests that efficient allocation of risk, firm abilities and investment performance have a positive influence on firm profitability and investment decisions. Therefore, this research proposes the following hypothesis:

Hypothesis 6 (H6). Project experience will positively affect private involvement in PPP.

\section{Methods}

\section{Data collection}

Company information is collected from the China economic and financial database of the China Center for Economic Research (CCER), which reported the financial information of the 1,125 private listed companies at 2015 ; the other way of gathering private firms' data is the company information system of the All-China Federation of Industry and Commerce (ACFIC), 
which serves the non-public economies in China.

Top 500 private companies in China reported by ACFIC in 2015 are selected in this research. These companies are ranked by income, and details are available on ACFIC's website (http://www.acfic.org.cn/zt/15/my500/index.html). Due to complexity of PPP projects, companies with high income have exemplary roles in participating. In addition, the authors also selected the company based on some requirements, such as enterprise strategy, industry, business scope, and firm type. In order to gain more information, two standards are used for selecting the firm and its respondent in the survey. Firstly, the target firms need to provide their financial reports or critical financial information for our research. Secondly, the target respondents need to be in a senior position to provide more information. The senior position means that the respondent is from the senior managers of the firm, including Chief Executive Officer (CFO), Chief Financial Officer (CFO), Chief Operating Officer (COO), General manager, and Senior project manager. These respondents have the authority to provide key suggestions for deciding whether to participate in PPP projects, especially for Chief Executive Officer (CFO), Chief Financial Officer (CFO), Chief Operating Officer (COO) and General manager, whose suggestions and proposals have an important impact on the investment decision on participating in PPP projects. Meanwhile, senior project managers possess rich experience in project construction and operation, which will provide reasonable and helpful suggestions for the decision-making on participating in PPP projects. From the database, the preliminary sample consists 2,078 companies, 342 out of top 500 private companies are selected.

All of the information used in this research is collected from the database including the firm 
status, financial information, project experiences and firm age. And the authors also gathered some information factors from the questionnaire, face-to-face, or telephone interviews.

\section{Variable specifications}

Dependent variables

The dependent variable, the willingness to participate in infrastructure PPP projects, is measured based on the investigation of the private company, which the binary variable set is 1 if the private company is willing to participate in infrastructure PPP projects, and 0 otherwise. Independent variables

The authors gained information on corporate financial status by calculating each company's debt-asset ratio. The variable debt-asset ratio is measured by taking into account debt and assets, and the data are from CCER and 2015 financial statements. The year 2015 is the time node, and the calculation length is only one year.

The variable profitability is measured by the return on assets (ROA) of each private company through financial data from CCER and 2015 financial statements. ROA is an indicator of how profitable a firm is relative to its total assets, which is calculated by dividing a firm's annual income by its total assets (Bodie et al., 2014). Again, the year 2015 is the time node, and the calculation length is only one year.

The variable political connection reflected the relationship between firm and politics, especially their membership in political parties (Faccio, 2006; Li et al., 2006; Zhou, 2013), the political connection is a binary variable, coded 1 if one of the company's large shareholders or top leaders is a member of NPC or CPPCC in China, 0 otherwise. 
The variable institution environment, government intervention, government support, project complexity, public support, and project experience are measured by the investigation of the private company, for which the binary variable is set to 1 if the private company considered this variable as an important factor in making decisions, and set to 0 if the private company considered this variable as an unimportant factor in decision making. The data are from a questionnaire survey, and Table 1 describes the item.

\section{Model specifications}

A research model for a private firm's willingness to participate in infrastructure PPP projects is proposed and showed in Figure 1.

Firstly, the dependent variable, the willingness to participate in PPP, is a binary and discrete choice, and the binary logistic model has its extensive applications in the literature and belongs to a broad category of "discrete choice models" (Cox, 1989; Stock and Watson, 2015). Secondly, the binary logistic regression model integrates the advantages of multiple regression analysis in a binary form and has the capabilities to address nonlinear relationships (Tabachnick and Fidell, 2007; Field, 2009). Therefore, this research employs a binary logistic regression model to study the private sector's willingness to participate in infrastructure PPP projects.

\section{Results}

\section{Data statistics and correlation analysis}

Between January and April 2016, a total of 2,078 questionnaires were distributed to participants in mainland China, but 1,150 replies were received with complete information. Respondents consist of five types of companies, i.e. construction firms, real estate companies, 
financial intermediaries, manufacturing enterprises, and internet platform companies. In this research, financial intermediaries included banks, investment firms, and insurance companies (Bodie et al., 2014). Regarding the role of respondents, $19.05 \%$ are from CFOs, $15.04 \%$ are from CFOs, $5.91 \%$ are from COOs, $32 \%$ are from General managers, $26 \%$ are from Senior project managers, and $2 \%$ are from the others (such as strategy manager). Of the respondents, $11.6 \%$ respondents had been in business for $1-5$ years, $23.1 \%$ for $6-10$ years, and $65.3 \%$ for more than 10 years. Six hundred and twenty-two participants (54.1\%) have PPP project experiences, and 44.7\% $(\mathrm{n}=514)$ are NPC or CPPCC members. Of the respondents, 53.2\% are willing to participate in infrastructure PPP projects. Other information is shown in Table 2.

In order to determine the correlation coefficients of the independent and dependent variables, the article uses Pearson's correlation analysis to test the variable correlation. Table 3 shows the means, standard deviations, and correlations of all variables used here. Due to the relatively high correlation between firm political connections and corporate financial status, the authors tested for multicollinearity in our predictor variables. The variance inflation factor (VIF) for each of these independent variables did not show significant multicollinearity (VIF < 3.45) and all below the commonly used cutoff of 10 , suggesting that multicollinearity is not a concern (Peng and Luo, 2000). Given that our dependent variable —-whether the private company is willing to participate in PPP projects—is dichotomous, the binary logistic regression is used to test the hypotheses.

\section{Logistic regression analysis verification}

Hypotheses are tested with three separate logistic regression models. Model I is the full 
model, consisting of all independent variables. In addition, according to Sampson (2005), Iossa \& Martimort (2012) and Bodie et al (2014), the experience can influence firms' willingness to participate in PPP projects by having a better understanding of organizational capabilities and risks allocation. In order to further analyze the effect of experience on willingness to participate, a subgroup analysis is conducted to test the different points on willingness to participate in experienced and inexperienced firm. Dummy variable is used of project experience, two subsamples are listed, labeled "experienced firms" and "inexperienced firms". Models II and III show the results for these two subsamples. Table 4 presents the goodness-of-fit of logistic regression models, the highly significant $\chi^{2}(\mathrm{p}<0.001)$ indicates a good fit with the data in all three models. Nonsignificant $(\mathrm{p}>0.001)$ results for the Hosmer-Lemeshow test in three models indicate a good fit.

Table 5 shows the results of the logistic regression analysis for the willingness to participate in PPP. If the variable is a positive coefficient, it means that the probability of private participation in PPP will increase, which can accurately interpret the parameters of the model.

In model I, with regard to the profitability variable, the correlation is positive and significant $(\mathrm{p}<0.1)$, which indicates that a one percent increase in firm profitability increased the odds of participating in PPP by 2.26 times, and it supports hypothesis H1a. As for corporate financial status, the correlation is not significant or positive for private participation in PPP (p > 0.1), and thus it rejects hypothesis H1b. Regarding the political connections, the correlation is positive and significant $(\mathrm{p}<0.05$ and $\mathrm{p}<0.01)$, which indicates that the odds of companies with political connection participating in PPP is approximately four times greater than those with no 
political connection, and it supports H1c. As for the institution environment, the correlation is not significant ( $p>0.1$ ), which suggests that hypothesis $\mathrm{H} 2$ is not supported by the sample data. With regard to the government support variable, the correlation is positive and significant $(\mathrm{p}<0.1)$, which indicates that projects with government support are two times more likely to attract private participate in PPP, and it supports hypothesis H3a. Regarding the government intervention, the correlation is significant $(\mathrm{p}<0.1$ and $\mathrm{p}<0.05)$, which suggests that projects without government intervention are $1.6(1 / 0.624)$ times more likely to attract private participating in PPP, and it supports H3b. As for the project complexity, the correlation is significant $(\mathrm{p}<0.05$ and $\mathrm{p}<0.01)$, which suggests that the odds of projects with low complexity attracting private participation is $1.8(1 / 0.545)$ times greater than those with high complexity, and it supports H4. Regarding the public support, the correlation is not significant ( $p>0.1$ ), which indicates that hypothesis $\mathrm{H} 5$ is not supported by the sample data in this model. As for the experience, the correlation is positive and significant $(\mathrm{p}<0.05$ and $\mathrm{p}<0.01)$, which suggests that the odds of companies with more project experiences participating in PPP is four times greater than those with less project experiences, and it supports hypothesis $\mathrm{H6}$.

Models II and III suggest that variables including profitability, political connections, government support, and project complexity, have important influence on firm's willingness to participation in PPP projects. It also shows that institution environment and public support are not supported by the sample data in this model. However, Model II suggests that government intervention has no impact on the experienced firms' willingness to participate in PPP, and the hypothesis $\mathrm{H} 3 \mathrm{~b}$ is not supported. In model II, political connections have the most important 
effect on experienced firms' willingness to participate in PPP. In addition, Model III shows that corporate financial status has a positive and significant correlation $(\mathrm{p}<0.1)$, which suggests that the odds of companies with strong financial status participating in PPP is approximately two times greater than those with weak financial status, and it supports hypothesis H1b.

\section{Discussions}

This research extends previous work by determining the factors that affect the willingness to participate in PPP projects. This suggests that both internal and external factors influence the firms' willingness to participate in infrastructure PPP projects.

To the internal factors, the findings show the firm's experience and profitability play an important role to participate in PPP projects. The experienced firms have an advantage over gaining the PPP project successfully, and in turn, this advantage also encourages the firms to participate in PPP projects. The experience can improve firms' capabilities and investment performance, because experience helps the firms decrease complexity or uncertainty to shape and refine their routines. In turn, the project complexity requires the partner to have different capabilities for supporting the operation of the PPP processes. On the other hand, firm's profitability influences firms' willingness to participate in PPP, which means more profitable firms may be more comfortable with taking on the risks of PPP work. This result also suggests that when the PPP projects have the potential to get a commensurate return, the firm will participate in transactions or make a positive investment decision.

To the external factors, political connections and government interventions have the positive and negative influences to the firms' willingness to participate in PPP projects. The political 
connections help the firms to gain some critical resources which they cannot gain from market, and helps firms secure favorable policies or tax conditions to increase firm's competitive advantage. The implications of political connections are also a growing interest in developing countries or in Low- and Middle-Income Countries. On the contrary, government interventions have negative influences in participating PPP projects. The project complexity also has the similar negative influence. The findings show that the excessive intervention of government and more complex projects will directly affect the firms' investment recovery, but establishing a consortium or alliance and promoting more explicit government intervention may be the other alternative.

Furthermore, the authors found no support for the effect of institutional environment and public support on firms' willingness to participate in PPP. According to the data analysis, more than $60 \%$ of the non-NPC or non-CPPCC respondents deem that a good relationship or guanxi with the government can secure favorable regulatory and reduce conflicts between firms and the public. And 58\% of the respondents suggest that collecting public opinions not only increases the costs of private participation in PPP, but also influences on making the investment decision negatively. Such arguments are similar to discussions from Boubakri et al. (2012) and Claessens et al. (2008) that politically connected firms enjoy a lower cost of equity capital and easier access to bank financing. In addition, De Los Ríos-Carmenado et al. (2016) also suggested that establishing the relationship with political organizations is an important factor for value creation and project performance in Madrid, Spain. However, political involvement may reduce firms' environmental uncertainty, but the better institution environment and public support are also 
essential to shape and monitor the private company's behavior, because lack of regulation or public involvement will increase the opportunism or rent-seeking that they are risky!

Finally, regarding these findings' generalizability, a comparative study on previous studies, the relationship with political organizations is an important factor for PPP project performance in Madrid, Spain (Kirama and Mayo, 2016, De Los Ríos-Carmenado et al., 2016); and keeping a close relationship with government is very important for businessmen or investors to gain more PPP market opportunities and resources in Low- and Middle-Income Countries (Farrell and Vanelslander, 2015). Thus, the authors can conclude that the effect of political connections on decision-making exactly existed, not only in China, but also in Low- and Middle-Income Countries. According to the PPP maturity model provided by Deloitte (Deloitte Research Closing the Infrastructure Gap, 2006), many governments in Low- and Middle-Income Countries are still at the first stage of PPP development. Developing a deep understanding of the challenges and potential solutions is important for them to move up the maturity curve. Therefore, according to previous statement, our research may contribute to the Low- and Middle-Income Countries or some countries at the first stage of PPP development for improving the PPP maturity.

\section{Conclusions and Limitations}

The research has identified and tested the factors in influencing private willingness to participate in infrastructure PPP projects. A logistic regression is used to determine the firms' willingness to participate in PPP projects from the private sector perspective. It is found that $53.2 \%$ of private companies are willing to participate in PPP projects, and nine critical factors are 
identified through a literature review. The relationship between the willingness to participate and its factors is explored and tested by the logistic regression model in the context of the Chinese PPP experience and practice. Although both internal (i.e., firm's financial status) and external factors (i.e., government support) variables influenced the willingness to participate in PPP, firm's project experience, profitability, and political connections appeared to be more powerful than the other variables in model I. Thus, the firms' willingness to participate in PPP must include firm's project experience, profitability, and political connections in addition to the more commonly studied government's or project's factors.

Although this research has tested the factors of willingness to participate in PPP from the private sector perspective, this study is not without limitations. First, some caution is necessary in generalizing these findings, as the data come from one country which may have distinguished aspects of economic, political, cultural and social environment. Second, as some variables are tested by the questionnaire, the validity of the data collected may be influenced by the possible difficulty in the respondents' understanding of those questions and their willingness to response those questions honestly. However, in order to reduce the effect of these limitations on the research, the authors have enhanced the comparison with previous study and deepened the interpretation and description to reduce the difficulty in the respondents' understanding of the questions. Besides, the logistical model has not taken into account different types of firms and position of the respondents in firm, so this limitation will be considered for future research. Future researchers may build more accurate models of private firms' willingness to participate in PPP by increasing the type of firm and capital market conditions, and incorporating the 
interactions among some independent variables. Overall, the research findings have contributed into the existing body of knowledge by clarifying the preconditions and factors of private investment in PPP projects.

\section{Data availability statement}

Data generated or analyzed during the study are available from the corresponding author by request. Information about the Journal's data sharing policy can be found here: http://ascelibrary.org/doi/10.1061/\%28ASCE\%29CO.1943-7862.0001263.

\section{References}

Akhmouch A., Kauffmann C., 2013. Private-sector participation in water service provision: revealing governance gaps. Water International, 38(3), 340-352.

Albalate D., Bel G., Geddes R. R., 2015. The determinants of contractual choice for private involvement in infrastructure projects. Public Money \& Management. 35(1), 87-94.

Altinay L., Brookes M., 2012. Factors influencing relationship development in franchise partnerships. Journal of Services Marketing. 26(4), 278-292.

Barney J. B., 1991. Firm resources and sustained competitive advantage. Journal of management. 17(1), 99-120.

Bodie Z., Kane A., Marcus A. J, 2014. Investments. Tenth edition. New York: McGraw-Hill Education.

Boubakri N., Cosset J. C., Saffar W., 2008. Political connections of newly privatized firms. Journal of Corporate Finance. 14, 654-673.

Boubakri N., Guedhami O., Mishra D., Saffar W., 2012. Political connections and the cost of 
equity capital. Journal of Corporate Finance. 18, 541-559.

Boussabaine A., 2014. Risk Pricing Strategies for Public-Private Partnership Projects. Wiley-Blackwell, Oxford, UK.

Bovaird T., 2004. Public-Private Partnerships: from Contested Concepts to Prevalent Practice. International Review of Administrative Sciences. 70(2), 199-215.

Boyer E J., Slyke D. M. V., Rogers J D., 2016. An Empirical Examination of Public Involvement in Public-Private Partnerships: Qualifying the Benefits of Public Involvement in PPPs. Journal of Public Administration Research And Theory. 26(1), 45-61.

Bray D., Sayeg P., 2013. Private sector involvement in urban rail: Experience and lessons from South East Asia. Research in Transportation Economics. 39, 191-201.

Burdett K., Coles M. G., 1999. Long-Term Partnership Formation: Marriage and Employment. The Economic Journal. 109(456), 307-334.

Cantor D. G., Lippman S. A., 1995. Optimal Investment Selection with a Multitude of Projects. Econometrica. 63(5), 1231-1240.

Chan A. P. C., Lam P. T. I., Chan D. W. M., Cheung E., Ke Y., 2010. Critical Success Factors for PPPs in Infrastructure Developments: Chinese Perspective. Journal of Construction Engineering and Management. 136(5), 484-494.

Chen Z., Zhang M., Si D., 2015. China's PPP Practice: Developments, Models, Problems and Solutions. International Economic Review. 4, 68-84.

Claessens S., Feijen E., Laeven L., 2008. Political connections and preferential access to finance: The role of campaign contributions. Journal of Financial Economics. 88, 554-580. 
Cleary S., 1999. The Relationship between Firm Investment and Financial Status. The Journal of Finance. 54(2), 673-692.

Cox D. D. R., 1989. The analysis of binary data. Boca Raton, FL: CRC Press.

Crosslin R. L., 1991. Decision-support methodology for planning and evaluating public-private partnerships. Journal of Urban Planning and Development. 117(1), 15-31.

Dailami M., Leipziger D., 1998. Infrastructure Project Finance and Capital Flows: A New Perspective. World Development. 26(7), 1283-1298.

De Los Ríos-Carmenado I., Ortuño M., Rivera M., 2016. Private-Public Partnership as a Tool to Promote Entrepreneurship for Sustainable Development: WWP Torrearte Experience. Sustainability. 8(3), 199-217.

Emerson R. M., 1962. Power-dependence relations. American Sociological Review. 27(1), $31-41$.

Engel E., Fischer R., Galetovic A., 2013. The Basic Public Finance of Public-Private Partnerships. Journal of the European Economic Association. 11(1), 83-111.

Faccio M., 2006. Politically Connected Firms. The American Economic Review. 96(1), 369-386.

Farquharson E., Mästle C., Yescombe E. R., 2011. How to Engage with the Private Sector in Public-Private Partnerships in Emerging Markets. The World Bank, Washington, DC.

Farrell S., Vanelslander T., 2015. Comparison of Public-Private Partnerships in Airports and Seaports in Low- and Middle-Income Countries. Transport Reviews: A Transnational Transdisciplinary Journal. 35(3), 329-351.

Field A. P., 2009. Discovering Statistics Using SPSS. 3rd ed. London: Sage. 
Fisher I., 1930. The Theory of Interest. New York: Macmillan.

Gatti S., 2013. Project Finance in Theory and Practice: Designing, Structuring, and Financing Private and Public Projects. USA: Elsevier Inc.

Grimsey D., Lewis M. K., 2004. Public private partnerships: The worldwide revolution in infrastructure provision and project finance. Northampton, MA: Edward Elgar.

Gross M., Garvin M., 2010. Configurational Comparative Methods for Aligning PPP Strategies with Public-Policy Objectives. Construction Research Congress, pp. 869-878.

Guasch J. L., Spiller P., 1999. Managing the Regulatory Process: Design, Concepts, Issues and the Latin America and Caribbean Story. The World Bank, Washington, D.C.

Ham H., Koppenjan J., 2001. Building public private partnerships: Assessing and managing risks in port development. Public Management Review. 3(4), 593-616.

Hart O., 2003. Incomplete Contracts and Public Ownership: Remarks, and an Application to Public-Private Partnerships. The Economic Journal. 113(486), 69-76.

Hirshleifer J., 1965. Investment decision under uncertainty: choice-theoretic approaches. The Quarterly Journal of Economics. 123(4), 509-537.

Hirth S., Viswanatha M., 2011. Financing constraints, cash-flow risk, and corporate investment. Journal of Corporate Finance. 17, 1496-1509.

Hodge G. A., Greve C., 2007. Public-Private Partnerships: An International Performance Review. Public Administration Review. 67, 545-558.

Iossa E., Martimort D., 2012. Risk allocation and the costs and benefits of public-private partnerships. RAND Journal of Economics. 43(3), 442-474. 
Jensen O., 2016. Public-private partnerships for water in Asia: a review of two decades of experience. International Journal of Water Resources Development. DOI: 10.1080/07900627. -2015.1121136.

Jin X., Zuo J., 2011. Critical Uncertainty Factors for Efficient Risk Allocation in Privately Financed Public Infrastructure Projects in Australia. International Journal of Construction Management. 11(3), 19-34.

Ke Y., Wang S., Chan A. P. C., 2013. Risk Misallocation in Public-Private Partnership Projects in China. International Public Management Journal. 16(3), 438-460.

Koppenjan J. F. M., 2005. The Formation of Public - Private Partnerships: Lessons from Nine Transport Infrastructure Projects in The Netherlands. Public Administration. 83(1), 135-157.

Koppenjan J. F. M., Enserink B., 2009. Public-Private Partnerships in Urban Infrastructures: Reconciling Private Sector Participation and Sustainability. Public Administration Review. 69(2), 284-296.

Kim H., Lee P., 2008. Ownership structure and the relationship between financial slack and R\&D investments: Evidence from Korean firms. Organization Science. 19(3), 404-418.

Kirama A., Mayo A. W., 2016. Challenges and prospects of private sector participation in solid waste management in Dar es Salaam City, Tanzania. Habitat International. 53, 195-205.

Kivleniece I., Quelin B. V., 2012. Creating and capturing value in public-private ties: A private actor's perspective. Academy of Management Review. 37(2), 272-299.

Levinthal D. A., March J. G., 1993.The myopia of learning. Strategic Management Journal. 14, 95-112. 
Li B., Akintoye A., Edwards P. J., Hardcastle C., 2005. Critical success factors for PPP/PFI projects in the UK construction industry. Construction Management and Economics. 23(5), 459-471.

Li H., Meng L., Zhang J., 2006. Why Do Entrepreneurs Enter Politics? Evidence from China. Economic Inquiry. 44(3), 559-578.

Li T. H.Y., Ng S. T., Skitmore M., 2012. Public participation in infrastructure and construction projects in China: From an EIA-based to a whole-cycle process. Habitat International. 36, 47-56.

Lin Y., 2013. Global infrastructure initiative and global recovery. Journal of Policy Modeling. 35, 400-411.

Liu J., Love P. E. D., Davis P. R., Smith J., Regan M., 2014. Conceptual Framework for the Performance Measurement of Public-Private Partnerships. Journal of Infrastructure Systems. DOI: 10.1061/(ASCE)IS.1943-555X.0000210, 04014023.

Mahoney J. T., McGahan A. M., Pitelis C. N., 2009. The Interdependence of Private and Public Interests. Organization Science. 20(6), 1034-1052.

Mayer J., 2007. Private Returns, Public Concerns: Addressing Private-Sector Returns in Public-Private Highway Toll Concessions. Transportation Research Record. 1996, 9-16.

Mouraviev N., Kakabadse N. K., 2015. Public-Private Partnership's Procurement Criteria: The case of managing stakeholders' value creation in Kazakhstan. Public Management Review. 17(6), 769-790.

Ng S. T., Wong Y. M. W., Wong J. M. W., 2010. A structural equation model of feasibility 
evaluation and project success for publicprivate partnerships in Hong Kong. IEEE Transactions On Engineering Management. 57(2), 310-322.

Nijmeijer K. J., Fabbricotti I. N., Huijsman R., 2014. Making FranchisingWork: A Framework Based on a Systematic Review. International Journal of Management Reviews. 16, 62-83.

Nijkamp P., Rienstra S. A., 1995. Private sector involvement in financing and operating transport infrastructure. The Annals of Regional Science. 29, 221-235.

North D. C., 1987. Institutions, transactions costs and economic growth. Economic Inquiry. 25, $419-428$

North D. C., 1991. Institutions. Journal of Economic Perspectives. 5(1), 97-112.

Osei-Kyei R., Chan A. P. C., 2015. Review of studies on the Critical Success Factors for Public-Private Partnership (PPP) projects from 1990 to 2013. International Journal of Project Management. 33, 1335-1346.

Ouenniche J., Boukouras A., Rajabi M., 2016. An Ordinal Game Theory Approach to the Analysis and Selection of Partners in Public-Private Partnership Projects. Journal of Optimization Theory and Applications. 169(1), 314-343.

Panayiotou A., Medda F., 2014. Attracting private sector participation in infrastructure investment: the UK case, Public Money \& Management, 34(6), 425-431,

Panda D. K., 2016. Public private partnerships and value creation: the role of relationship dynamics. International Journal of Organizational Analysis. 24(1), 162-183.

Peng M. W., Luo Y., 2000. Managerial ties and firm performance in a transition economy: The nature of a micro-macro link. Academy of Management Journal. 43, 486-501. 
Percoco M., 2014. Quality of institutions and private participation in transport infrastructure investment: Evidence from developing countries. Transportation Research Part A. 70, 50-58.

Pfeffer J., Salancik G. R., 2003. The external control of organizations: A resource dependence perspective. Stanford, CA: Stanford University Press.

Queiroz C., Vajdic N., Mladenovic G., 2013. Public-private partnerships in roads and government support: trends in transition and developing economies. Transportation Planning and Technology. 36(3), 231-243.

Ranasinghe M., 1998. Thoughts on a methodology to analyse viability of private-sector participation in new infrastructure projects in developing countries. Impact Assessment and Project Appraisal. 16(3), 203-213.

Reeves E., 2008. The practice of contracting in public private partnerships : transaction costs and relational contracting in the Irish. Public Administration. 86(4), 969-986.

Regan M., Smith J., Love P., 2011. Infrastructure procurement: learning from private-public partnership experiences 'down under'. Environment and Planning C: Government and Policy. 29, 363-378.

Regan M., Love P. E. D., Smith J., 2013. Public-Private Partnerships: Capital Market Conditions and Alternative Finance Mechanisms for Australian Infrastructure Projects. Journal of Infrastructure Systems. 19(3), 335-342.

Sampson R. C., 2005. Experience Effects and collaborative returns in R\&D Alliances. Strategic Management Journal. 26, 1009-1031. 
Savas E. S., 2000. Privatization and public-private partnerships. New York: Chatham House Publishers.

Sclar E., 2015. The political economics of investment Utopia: public-private partnerships for urban infrastructure finance. Journal of Economic Policy Reform. 18(1), 1-15.

Shen L.Y., Li H., Li Q. M., 2002. Alternative concession model for build operate transfer contract projects. Journal of Construction Engineering Management. 128(4), 326-330.

Shen L., Tam V. W., Gan L., Ye K., Zhao Z., 2016. Improving Sustainability Performance for Public-Private-Partnership (PPP) Projects. Sustainability. 8(3), 289-303.

Siemiatycki M., 2011. Public-Private Partnership Networks: Exploring Business-Government Relationships in United Kingdom Transportation Projects. Economic Geography. 87(3), 309-334.

Smith R. G. E., 1971. Uncertainty, Information and Investment Decisions. The Journal of Finance. 26(1), 67-82.

Soliño A. S., Santos P. G. D., 2016. Influence of the Tendering Mechanism in the Performance of Public-Private Partnerships: A Transaction Cost Approach. Public Performance \& Management Review. DOI: 10.1080/15309576.2016.1177558.

Song B., Xu F., 2011. Partner-Selection in Public-Private Partnership Project Based on an Iterative Algorithm for the Multi-objective Group Decision Problem. Journal of Systems and Management. 20(6), 690-695.

Song J., Zhang H., Dong W., 2016. A review of emerging trends in global PPP research: analysis and visualization. Scientometrics. 107, 1111-1147. 
Soomro M. A., Zhang X., 2015. Roles of Private-Sector Partners in Transportation Public-Private Partnership Failures. Journal of Management in Engineering. 31(4), 04014056.

Steijn B., Klijn E., Edelenbos J., 2011. Public Private Partnerships: Added Value by Organizational Form or Management?. Public Administration. 89(4), 1235-1252.

Stock J. H., Watson M. W., 2015. Introduction to econometrics. Third edition update. UK: Pearson Education, Inc.

Tabachnick B. G., Fidell L. S., 2007. Using Multivariate Statistics. New York: Pearson.

Tecco N., 2008. Financially sustainable investments in developing countries water sectors: what conditions could promote private sector involvement?. International Environmental Agreements: Politics, Law and Economics. 8, 129-142.

Tiong R. L.K., Yeo K. T., Mccarthy S. C., 1992. Critical success factors in winning BOT contracts. Journal of Construction Engineering and Management. 118(2), 217-228.

Tiong R. L. K., 1996. CSFs in Competitive Tendering and Negotiation Model for BOT Projects. Journal of Construction Engineering and Management. 122(3), 205-211.

Vining A. R., Boardman A. E., 2008. Public-Private Partnerships Eight Rules for Governments. Public Works Management and Policy. 13(2), 149-161.

Wang S., Tiong R. L. K., Ting S. K., Ashley D., 2000. Evaluation and Management of Political Risks in China's BOT Projects. Journal of Construction Engineering and Management. $126(3), 242-250$.

Wibowo A., Alfen H. W., 2015. Government-led critical success factors in PPP infrastructure development. Built Environment Project and Asset Management. 5(1), 121-134. 
Williamson O. E., 1999. Public and private bureaucracies. Journal of Law, Economics and Organization. 15(1), 306-342.

Xu Y., Yeung J. F. Y., Jiang S., 2014. Determining appropriate government guarantees for concession contract: lessons learned from 10 PPP projects in China. International Journal of Strategic Property Management. 18(4), 356-367.

York J. G., Sarasvathy S. D., Wicks A. C., 2013. An Entrepreneurial Perspective on Value Creation in Public-Private Ventures. Academy of Management Review. 38(2), 307-315.

Yun S., Jung W., Han S., Park H., 2015. Critical organizational success factors for public private partnership projects-a comparison of solicited and unsolicited proposals. Journal of Civil Engineering and Management. 21(2), 131-143.

Zhang H., Li L., Zhou D., Zhou P., 2014. Political connections, government subsidies and firm financial performance: Evidence from renewable energy manufacturing in China. Renewable Energy. 63, 330-336.

Zhang S., Gao Y., Feng Z., Sun W., 2015. PPP application in infrastructure development in China: Institutional analysis and implications. International Journal of Project Management. 33, 497-509.

Zhang X., 2005a. Critical success factors for public-private partnerships in infrastructure development. Journal of Construction Engineering and Management. 131(1), 3-14.

Zhang X., 2005b. Criteria for Selecting the Private-Sector Partner in Public-Private Partnerships. Journal of Construction Engineering and Management. 131(6), 631-644.

Zhang X., Soomro A. M., 2015. Failure Path Analysis with Respect to Private Sector Partners in 
Transportation Public-Private Partnerships. Journal of Management in Engineering. 10.1061/(ASCE)ME.1943-5479.0000384, 04015031.

Zhang Y., 2014. From State to Market: Private Participation in China's Urban Infrastructure Sectors, 1992-2008. World Development. 64, 473-486.

Zhong T., Young R. K., Lowry M., Rutherford G. S., 2008. A model for public involvement in transportation improvement programming using participatory Geographic Information Systems. Computers, Environment and Urban Systems. 32, 123-133.

Zhou W., 2013. Political connections and entrepreneurial investment: Evidence from China's transition economy. Journal of Business Venturing. 28, 299-315.

Zou W., Kumaraswamy M., Chung J., Wong J., 2014. Identifying the critical success factors for relationship management in PPP projects. International Journal of Project Management. 32, 265-274.

Fig. 1 Research model for Private involvement in PPP 
Table 1. Items on the questionnaire

\begin{tabular}{|c|c|c|}
\hline Items & Description & Categories \\
\hline $\begin{array}{l}\text { Institutional environment have an important effect on } \\
\text { private company's willingness to participate in PPP } \\
\text { projects. }\end{array}$ & $\begin{array}{l}\text { Private Companies agree that institutional environment is an important factor of } \\
\text { participation decision-making in terms of lower corruption, civil freedom, and a better } \\
\text { regulatory framework. }\end{array}$ & $\mathrm{Yes}=1, \mathrm{No}=0$ \\
\hline $\begin{array}{l}\text { Government intervention has an important effect on private } \\
\text { company's willingness to participate in PPP projects. }\end{array}$ & $\begin{array}{l}\text { Government intervention means that government will intervene in controlling the } \\
\text { firms' operation strategy for PPP projects, delay the approvals, and limit the price } \\
\text { setting and adjustment too much. }\end{array}$ & $\mathrm{Yes}=1, \mathrm{No}=0$ \\
\hline $\begin{array}{l}\text { Government support has an important effect on private } \\
\text { company's willingness to participate in PPP projects. }\end{array}$ & $\begin{array}{l}\text { Government support involves government commitment, revenue or financial } \\
\text { guarantee, trust, and information transparency. }\end{array}$ & $\mathrm{Yes}=1, \mathrm{No}=0$ \\
\hline $\begin{array}{l}\text { Project complexity has an important effect on private } \\
\text { company's willingness to participate in PPP projects. }\end{array}$ & $\begin{array}{l}\text { Project complexity main involves financial, technical and management of PPP } \\
\text { projects. }\end{array}$ & $\mathrm{Yes}=1, \mathrm{No}=0$ \\
\hline $\begin{array}{l}\text { Public support has an important effect on private } \\
\text { company's willingness to participate in PPP projects. }\end{array}$ & $\begin{array}{l}\text { Public support main involves the willingness-to-pay, their view on the project, } \\
\text { acceptance for the output from the PPP projects, and support on acquisition of lands. }\end{array}$ & $\mathrm{Yes}=1, \mathrm{No}=0$ \\
\hline The firm possesses the PPP project experience. & Firms have engaged in PPP projects. & $\mathrm{Yes}=1, \mathrm{No}=0$ \\
\hline The firm has established the relationship with politic. & The company's large shareholders or top leaders are the member of NPC or CPPCC. & $\mathrm{Yes}=1, \mathrm{No}=0$ \\
\hline The firm is willing to participate in PPP projects & & $\mathrm{Yes}=1, \mathrm{No}=0$ \\
\hline
\end{tabular}


Table 2. Sample description

\begin{tabular}{|c|c|c|c|}
\hline Items & Categories & Frequency & Percent \\
\hline \multirow[t]{3}{*}{ Firm age } & $\leq 5$ years & 133 & $11.6 \%$ \\
\hline & $6-10$ years & 266 & $23.1 \%$ \\
\hline & $\geq 10$ years & 751 & $65.3 \%$ \\
\hline \multirow{2}{*}{ PPP project experience } & Experienced Firms & 622 & $54.10 \%$ \\
\hline & Inexperience Firms & 528 & $45.90 \%$ \\
\hline \multirow[t]{5}{*}{ Type of Company } & Construction Firms & 482 & $41.91 \%$ \\
\hline & Real Estate Companies & 118 & $10.26 \%$ \\
\hline & Financial Intermediaries & 236 & $20.52 \%$ \\
\hline & Manufacturing Enterprises & 146 & $12.70 \%$ \\
\hline & Internet Platform Companies & 168 & $14.61 \%$ \\
\hline \multirow[t]{2}{*}{ Firm's political role } & Member of NPC or CPPCC & 514 & $44.70 \%$ \\
\hline & Nothing & 636 & $55.30 \%$ \\
\hline Role of respondent in & Chief Executive Officer & 219 & $19.05 \%$ \\
\hline \multirow[t]{5}{*}{ firm } & Chief Financial Officer & 173 & $15.04 \%$ \\
\hline & Chief Operating Officer & 68 & $5.91 \%$ \\
\hline & General manager & 368 & $32 \%$ \\
\hline & Senior project manager & 299 & $26 \%$ \\
\hline & others & 23 & $2 \%$ \\
\hline
\end{tabular}


Table 3. Descriptive Statistics and Correlations

\begin{tabular}{|c|c|c|c|c|c|c|c|c|c|c|c|}
\hline Variables & Mean & s.d. & 1 & 2 & 3 & 4 & 5 & 6 & 7 & 8 & 9 \\
\hline Private involvement & 0.53 & 0.499 & & & & & & & & & \\
\hline Corporate financial status & $59 \%$ & 0.407 & $0.225^{\mathrm{a}}$ & & & & & & & & \\
\hline Firm profitability & $3.8 \%$ & 0.382 & $0.159^{\mathrm{a}}$ & $0.287^{\mathrm{a}}$ & & & & & & & \\
\hline Firm political connections & 0.446 & 0.497 & $0.146^{\mathrm{a}}$ & $0.465^{\mathrm{a}}$ & $0.324^{\mathrm{a}}$ & & & & & & \\
\hline Institutional environment & 0.49 & 0.500 & 0.027 & $0.102^{\mathrm{c}}$ & $0.186^{\mathrm{a}}$ & $0.141^{\mathrm{b}}$ & & & & & \\
\hline Government intervention & 0.47 & 0.498 & $-0.244^{\mathrm{a}}$ & $-0.135^{\mathrm{a}}$ & $-0.158^{a}$ & -0.040 & $-0.103^{c}$ & & & & \\
\hline Government support & 0.78 & 0.414 & $0.442^{\mathrm{a}}$ & $0.126^{\mathrm{a}}$ & $0.115^{\mathrm{a}}$ & $0.145^{\mathrm{b}}$ & 0.077 & $-0.224^{a}$ & & & \\
\hline Project complexity & 0.56 & 0.496 & $-0.424^{\mathrm{a}}$ & $-0.198^{\mathrm{a}}$ & -0.015 & -0.057 & $0.115^{\mathrm{a}}$ & 0.078 & $-0.097^{c}$ & & \\
\hline Public support & 0.42 & 0.494 & $0.076^{\mathrm{b}}$ & 0.041 & $0.151^{\mathrm{c}}$ & -0.015 & $0.087^{\mathrm{b}}$ & $-0.097^{\mathrm{b}}$ & 0.062 & -0.016 & \\
\hline PPP Project experience & 0.530 & 0.395 & 0.113 & $0.211^{\mathrm{b}}$ & $0.302^{\mathrm{c}}$ & 0.154 & 0.226 & $0.119^{c}$ & 0.121 & 0.203 & -0.053 \\
\hline
\end{tabular}

Note: Sample size is 1150.

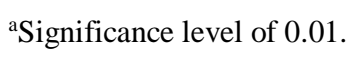

${ }^{\mathrm{b}}$ Significance level of 0.1 .

${ }^{\mathrm{c}}$ Significance level of 0.05 . 
Table 4. Logistic regression goodness of fit measures

\begin{tabular}{cccc}
\hline \multirow{2}{*}{ Model fit statistics } & Whole sample & Experienced firms & Inexperienced firms \\
\cline { 2 - 4 } & Model I & Model II & Model III \\
\hline$\chi^{2}$ & $322.774($ Sig. $=0.000)$ & $209.395($ Sig. $=0.000)$ & $135.706($ Sig. $=0.000)$ \\
-2Log Likelihood & 84.693 & 76.115 & 61.387 \\
Hosmer-Lemeshow & $13.898($ Sig. $=0.184)$ & $13.897($ Sig. $=0.180)$ & $7.799($ Sig. $=0.453)$ \\
Cox and Snell $\mathrm{R}^{2}$ & 0.444 & 0.478 & 0.436 \\
Nagelkerke $\mathrm{R}^{2}$ & 0.622 & 0.656 & 0.574 \\
Sample size & 1150 & 622 & 528 \\
\hline
\end{tabular}


Table 5. Logistic regression results

\begin{tabular}{|c|c|c|c|c|c|c|}
\hline \multirow{4}{*}{ Variables } & \multicolumn{6}{|c|}{ Willingness to Participate in PPP } \\
\hline & \multirow{2}{*}{\multicolumn{2}{|c|}{$\begin{array}{c}\text { Whole sample } \\
\text { Model I }\end{array}$}} & \multirow{2}{*}{\multicolumn{2}{|c|}{$\frac{\text { Experienced firms }}{\text { Model II }}$}} & \multirow{2}{*}{\multicolumn{2}{|c|}{$\begin{array}{c}\text { Inexperienced firms } \\
\text { Model III }\end{array}$}} \\
\hline & & & & & & \\
\hline & $\mathrm{B}$ & $\operatorname{Exp}(B)$ & $\mathrm{B}$ & $\operatorname{Exp}(B)$ & $\mathrm{B}$ & $\operatorname{Exp}(B)$ \\
\hline \multirow{2}{*}{$\begin{array}{c}\text { Firm profitability } \\
\text { Corporate financial } \\
\text { status }\end{array}$} & $0.817^{\mathrm{a}}$ & 2.264 & $0.704^{\mathrm{a}}$ & 2.022 & $0.723^{\mathrm{a}}$ & 2.061 \\
\hline & 0.141 & 1.151 & 0.271 & 1.311 & $0.398^{\mathrm{a}}$ & 1.489 \\
\hline $\begin{array}{l}\text { Firm political } \\
\text { connections }\end{array}$ & $1.325^{\mathrm{b}}$ & 3.762 & $1.382^{\mathrm{b}}$ & 3.983 & $0.692^{\mathrm{b}}$ & 1.998 \\
\hline $\begin{array}{l}\text { Institutional } \\
\text { environment }\end{array}$ & 0.031 & 1.031 & 0.103 & 1.108 & 0.286 & 1.331 \\
\hline Government support & $0.733^{\mathrm{a}}$ & 2.081 & $0.365^{\mathrm{a}}$ & 1.441 & $0.766^{\mathrm{a}}$ & 2.151 \\
\hline $\begin{array}{l}\text { Government } \\
\text { intervention }\end{array}$ & $-0.471^{\mathrm{c}}$ & 0.624 & -0.531 & 0.588 & $-0.413^{\mathrm{a}}$ & 0.662 \\
\hline Project complexity & $-0.607^{b}$ & 0.545 & $-0.425^{\mathrm{b}}$ & 0.654 & $-0.509^{\mathrm{b}}$ & 0.601 \\
\hline Public support & -0.124 & 0.883 & -0.336 & 0.715 & 0.051 & 1.052 \\
\hline $\begin{array}{l}\text { PPP Project } \\
\text { experience }\end{array}$ & $1.413^{\mathrm{b}}$ & 4.108 & & & & \\
\hline Constant & $-4.13^{b}$ & 0.016 & $-3.371^{\mathrm{b}}$ & 0.034 & $-3.002^{\mathrm{b}}$ & 0.050 \\
\hline Sample size & & & & & & \\
\hline
\end{tabular}

${ }^{\mathrm{a}}$ Significance level of 0.1 .

${ }^{\mathrm{b}}$ Significance level of 0.01 .

${ }^{\mathrm{c}}$ Significance level of 0.05 . 